\title{
The healthfulness and prominence of sugar in child-targeted breakfast cereals in Canada
}

\author{
Monique Potvin Kent, PhD (1); Cher Cameron, BSc (2); Sarah Philippe, BSc (2)
}

This article has been peer reviewed.

Tweet this article

\begin{abstract}
Introduction: The objective of this study was to compare the nutritional content and healthfulness of child-targeted and "not child-targeted" breakfast cereals and to assess the predominance of added sugar in these products.

Methods: We collected data on the nutritional content of 262 unique breakfast cereals found in the five largest grocery store chains in Ottawa (Ontario) and Gatineau (Quebec). We noted the first five ingredients and the number of added sugars present in each cereal from the ingredients list. The various cereal brands were then classified as either "healthier" or "less healthy" using the UK Nutrient Profile Model. We assessed each cereal to determine if it was child-targeted or not, based on set criteria. Statistical comparisons were made between child and not child-targeted cereals.
\end{abstract}

Results: $19.8 \%$ of all breakfast cereals were child-targeted, and these were significantly lower in total and saturated fat. Child-targeted cereals were significantly higher in sodium and sugar and lower in fibre and protein, and were three times more likely to be classified as "less healthy" compared to not child-targeted cereals. No child-targeted cereals were sugar-free, and sugar was the second most common ingredient in $75 \%$ of cereals. Six breakfast cereal companies had child-targeted product lines that consisted entirely of "less healthy" cereals.

Conclusion: There is a need for regulations that restrict food marketing to children and youth under the age of 17 on packaging to reduce their appeal to this age group. Children's breakfast cereals also need to be reformulated through government-set targets, or through regulation should compliance be deemed unacceptable.

Keywords: breakfast, children, nutrition, cereal, obesity, food supply, sugar, marketing

\section{Introduction}

The developed world has experienced a substantial increase in childhood overweight and obesity, with rates doubling between 1980 and 2008. ${ }^{1}$ This has led to an increased risk of cardiovascular diseases, diabetes, musculoskeletal disorders and various cancers globally. ${ }^{2}$ The rate of childhood obesity in Canada has increased dramatically over the last three decades from $2 \%$ in 1981 to $12 \%$ in 2009 to 2011 , and the combined rate of overweight and obesity in children aged between 5 and 17 years currently stands at $31.5 \%$. $^{3,4}$
Food and beverage marketing has been associated with childhood obesity, in addition to children's food preferences, short-term food intake and food requests. ${ }^{5,6}$ Research has shown that the majority of the products being advertised to children and youth are high in fat, sugar and sodium, with little nutritional value. ${ }^{7-9}$ The World Health Organization (WHO) has recommended that countries limit the volume of food and beverage marketing seen by children in all media forms, and in places where children gather. ${ }^{10}$ The former includes package labelling. Food and beverage marketing in Canada is mostly
Highlights

- Compared to not child-targeted cereals, child-targeted cereals were - significantly lower in fibre, protein, total fats and saturated fat; and - significantly higher in sodium and sugar.

- Child-targeted cereals were three times more likely to be categorized as "less healthy" than not childtargeted cereals.

- There were no child-targeted cereals that were sugar-free, and the majority contained two to three types of added sugar.

- Six breakfast cereal companies had child-targeted product lines that consisted entirely of "less healthy" cereals.

self-regulated by industry through the Children's Food and Beverage Advertising Initiative (CAI). ${ }^{11}$ The CAI was launched in 2007 by 16 food and/or beverage companies that pledged either to advertise only healthier products or to stop advertising to children under the age of 12 years on television, radio and print and in digital media (such as on the Internet and on smartphones). No pledges have been made with regard to food wrapping or package labels. In Quebec, all commercial advertising to children under the age of 13 years is prohibited through the Consumer Protection Act (CPA), which was implemented in 1980 to protect children from marketing in general. ${ }^{12}$ This law prohibits advertising to children in most media forms, including television and the Internet, in schools and daycare centres. Package labelling is excluded, however, so 
children in Canada are not protected from marketing on packaged products in any jurisdiction.

Breakfast cereals are a product category that is heavily marketed to children. In the US, research has shown that on average, in 2015 , children aged 2 to 11 years viewed over 500 breakfast cereal ads on television alone, ${ }^{13}$ and in 2009 , cereal marketing to children ranked second in terms of advertising spending, falling behind only quick service restaurant ad spending. ${ }^{14}$ In Canada, children aged 2 to 11 years view on average 33 breakfast cereal ads per month on television alone. ${ }^{15}$ Breakfast cereal is the third most frequently advertised product category and constitutes $11 \%$ of the advertising on both children's television and on children's preferred websites. ${ }^{16,17}$

In the United States, research has shown that the nutritional content of breakfast cereals targeted at children is extremely poor. ${ }^{18-19}$ An analysis of all child-targeted foods sold in Canadian supermarkets in 2008 showed that $93 \%$ of breakfast cereals derived over $20 \%$ of their calories from sugar. $^{20}$ Higher sugar intake by children (and particularly sugar-sweetened beverages) has been shown through meta-analysis to be associated with a higher risk of obesity. ${ }^{21}$ Results such as these are cause for concern among public health officials.

No Canadian study has specifically focussed on the overall nutritional content of breakfast cereals that target children or has compared child-targeted cereals to those not directed at children. Given the high prevalence of breakfast cereal marketing to children, the primary objective of our research was to compare the nutritional content and healthfulness of child-targeted and not child-targeted breakfast cereals. A secondary objective was to determine the predominance of added sugar in children's breakfast cereals in Canada. This latter objective is particularly salient, as Health Canada has recently reviewed food labelling regulations and has proposed that sugars be grouped in the ingredients list to allow consumers to more easily identify sources of sugar in food products. $^{22}$ It was expected that breakfast cereals targeted at children would be less healthy than cereals not targeted at children, and would contain a larger amount of sugar. Finally, the third objective of this study was to determine which companies should improve the healthfulness of their cereals marketed to children.

\section{Methods}

We designed a cross-sectional study to assess the nutritional content and healthfulness of the child-targeted and not-child targeted cereals.

\section{Collection of nutritional data}

Three undergraduate-level research assistants in their fourth year of study visited a convenience sample in Ottawa (Ontario) and Gatineau (Quebec) of the top five food retailers in Canada according to sales, ${ }^{23}$ including Loblaws, Sobeys (owned by Empire Co.), Metro, Costco and WalMart, and compiled a list of all cold breakfast cereals sold. They removed duplicates and recorded company names. A research assistant then visited the stores in question and took photos of each side of every cereal box on the list. The nutritional information of each cereal (without milk added) was taken directly from the Nutrition Facts table on the box. The nutritional information collected included the serving size (g), total number of calories (cal), trans fat (g), saturated fat (g), sodium (mg), fibre (g), sugar (g) and protein $(\mathrm{g})$. With the exception of trans fats, the collection of these nutrients was required in order to classify foods as "healthier" or "less healthy." We collected trans fats regardless, as they have been shown to be particularly harmful to health, given that they increase serum low-density lipoprotein (LDL) and lower serum high-density lipoprotein (HDL) levels. ${ }^{24}$

For each cereal, the number of added sugars was obtained from the ingredients list, and their place in the ingredients list was noted. Health Canada regulations specify that ingredients on prepackaged food products must be declared according to their weight and in descending order. ${ }^{25}$ Added sugars included the presence of agave, brown sugar, cane sugar or evaporated cane juice, concentrated fruit juice, corn syrup, dextrose or dextrin, fructose, galactose, glucose, glucose-fructose, high fructose corn syrup, honey, invert sugar, liquid sugar, maltose, maple syrup, molasses, nectar, raw sugar, sucrose, syrup and white sugar. Next, the first five ingredients presented in the cereal ingredient lists were noted in the order in which they appeared.

\section{Nutritional classification}

Foods were classified as either "healthier" or "less healthy" using the three-step UK Nutrient Profile Model developed by the UK Food Standards Agency. ${ }^{26}$ This nutrient model was selected because it has good validity and reliability, ${ }^{27,28}$ and has been used effectively in various research studies to accurately determine the nutritional quality of foods. ${ }^{7,29}$ To conduct this classification, each nutrient was converted to $100 \mathrm{~g}$ of the cereal and points were allocated based on the amount of energy $(\mathrm{kJ})$, saturated fat (g), total sugar (g), protein (g), fibre (g), sodium(mg) and the percentage of fruits, vegetables and nuts according to tables provided by a guidance report on the UK Nutrient Profile Model. ${ }^{26}$ The following calculation was then completed for each cereal: (energy points + saturated fat points + sugar points + sodium points) (fruit, vegetable and nuts percentage points + fibre points + protein points). A product with less than four points was considered "healthier" and those with four or more points were considered "less healthy."26

\section{Assessment of child-targeting}

The definition of "child-targeted" we used was based on previous research on food and beverage marketing to children on packaging and on television..$^{20,30} \mathrm{~A}$ breakfast cereal was considered to be directed towards children if it featured candy; child-directed images (e.g. cartoons); child-directed messages designed to get their attention (e.g. "Hey Kidz"); encouraged their interaction with the product (e.g. puzzles or games); mentioned children in their brand name or logo; included tie-ins to children's TV shows, movies, or musical acts; or used primary colours and cartoon-like fonts in order to appeal to children. If none of the items from the above list applied, the cereal was classified as "not child-targeted." To conduct this classification, all six sides of the cereal boxes were examined by two of the research assistants and any disagreements were resolved by the principal researcher. Interrater reliability was $95 \%$ and was calculated as follows: 1 - (12 disagreements / 262 cereals $) \times 100$. All data collection was conducted in the fall of 2015.

\section{Statistical analysis}

We conducted statistical analyses using IBM SPSS Statistics version 23.0 (IBM Corp., Armonk, NY, USA). An analysis of the mean $(\overline{\mathrm{x}})$ and standard deviation (SD) of each 
nutrient was conducted for the total sample and then for child-targeted and not childtargeted cereals. We completed $t$ tests to assess whether differences were statistically significant. We computed the number of "healthier" and "less healthy" breakfast cereals, and calculated chi square $\left(\chi^{2}\right)$ and the odds ratio to assess differences between child-targeted and not child-targeted cereals. Next, the number of child-targeted and not child-targeted "healthier" and "less healthy" cereals per company was determined. Companies with few cereal products (i.e. fewer than five products) were collapsed into an "other company" category. The companies in this category included Dorset Cereal, Small Planet Foods, A\&V 2000 Inc., Fourmi Bionique, naturSource, Empire Company Limited, Food for Life, GoGo Quinoa, Swissli, Wal-Mart and WildRoots. Finally, the number of sugars per cereal and the ordering of ingredients were tabulated and descriptive statistics were used to examine the proportion of foods that contained added sugar and to calculate the number of times that added sugar appeared in the ingredients list.

\section{Results}

The total number of unique breakfast cereals located was 266; however, four cereals were not found during subsequent visits to the grocery stores as they had been discontinued. Therefore, we analyzed 262 cereals. Fifty-two (19.8\%) of 262 cereals were found to target children. On average, child-targeted cereals were significantly higher in both sodium (containing $439.7 \mathrm{mg}$ on average, compared to not child-targeted cereals, which had $266.2 \mathrm{mg}$ ) and sugar (containing $30.2 \mathrm{~g}$ on average, compared to not child-targeted cereals, which had
19.2 g) (Table 1). Child-targeted cereals were also significantly lower in fibre (containing $5.2 \mathrm{~g}$ on average compared to not child-targeted cereals with $9.6 \mathrm{~g}$ ), as well as protein (containing $6.3 \mathrm{~g}$ on average compared to not child-targeted cereals with 10.0 g on average). In contrast, childtargeted cereals were significantly lower in total fat (containing $3.6 \mathrm{~g}$ on average compared to not child-targeted cereals with $7.2 \mathrm{~g}$ ) and saturated fat (containing $0.7 \mathrm{~g}$ on average compared to not childtargeted cereals with $1.5 \mathrm{~g}$ ). The majority of both child-targeted and not child-targeted cereals were classified as "less healthy" by the UK Nutrient Profile Model (as shown in Table 2) and there was a significant association between healthfulness and childtargeting $\left(\chi^{2}=7.6(d f=1), p=.006\right)$. Child-targeted cereals were 3.0 times more likely to be classified as "less healthy" compared to not child-targeted cereals.

Overall, only $7.3 \%(n=19)$ of breakfast cereals were sugar-free and the greatest number of cereals had between two and three types of sugar ( $\mathrm{n}=127 ; 48.5 \%)$ as shown in Table 3 . No child-targeted cereals were sugar-free and the greatest number $(\mathrm{n}=31 ; 59.6 \%$ ) contained 2 to 3 types of added sugars. A total of $9 \%(n=19)$ of not child-targeted cereals were sugar-free and $45.7 \%(n=96)$ contained 2 to 3 different added sugars. Almost $6 \%$ of these cereals $(n=12)$, contained between 7 and 11 different types of sugar.

Overall, the most common first ingredient was oats $(38.9 \%)$, while sugar was the most common second and third ingredient ( $44.3 \%$ and $35.5 \%$, respectively) as shown in Table 4. The most common first ingredient in child-targeted cereals was corn $(30.8 \%)$, followed by whole wheat $(26.9 \%)$ and oats $(19.2 \%)$. Sugar was the most common second and third ingredient $75 \%$ and $32.7 \%$ ) for child-targeted cereals. For not child-targeted cereals, the most common first ingredient was oats $(43.8 \%)$, followed by whole wheat $(16.7 \%)$ and rice $(11.9 \%)$. The most common second and third ingredient for these cereals was sugar, in $26.7 \%$ and $36.2 \%$ of cases, respectively.

The majority of each company's breakfast cereal offerings consisted of "less healthy" cereals, as shown in Table 5, with the exception of Weetabix, which was the only company that had a greater number of cereals falling into the "healthier" category. The companies with the highest number of "less healthy" cereals consisted of General Mills and Kellogg's (each with $\mathrm{n}=31$ "less healthy" cereals), Nature's Path Foods (n = 29), and President's Choice $(n=19)$. Kellogg's had the greatest number of child-targeted cereals $(n=16)$ followed by General Mills ( $\mathrm{n}=14$ ), Metro $(\mathrm{n}=6)$, and Nature's Path $(\mathrm{n}=5)$. Jordan's, Love Grown Foods and President's Choice had no child-targeted cereals. All (100\%) of the child-targeted cereals owned by General Mills, Metro, Nature's Path Foods, Post, Quaker and Sally's were classified as "less healthy."

\section{Discussion}

This study found that $85 \%$ of child-targeted breakfast cereals sold in the OttawaGatineau region were "less healthy," according to the UK Nutrient Profile Model, and that these cereals were three

TABLE 1

Average nutrients per $100 \mathrm{~g}$ of child-targeted and not child-targeted breakfast cereals sold in Ottawa and Gatineau, Canada

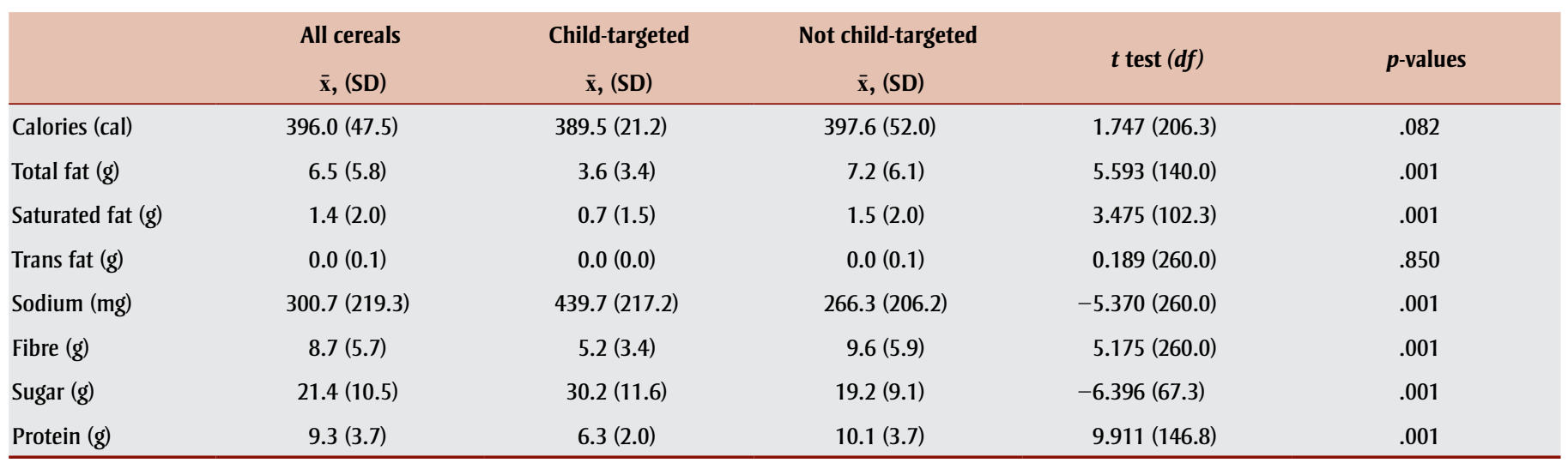

Abbreviations: $d f$, degrees of freedom; SD, standard deviation; $\bar{x}$, mean. 
TABLE 2

Number and percentage of child-targeted and not child-targeted breakfast cereals classified as "healthier" and "less healthy" according to the UK Nutrient Profile Model

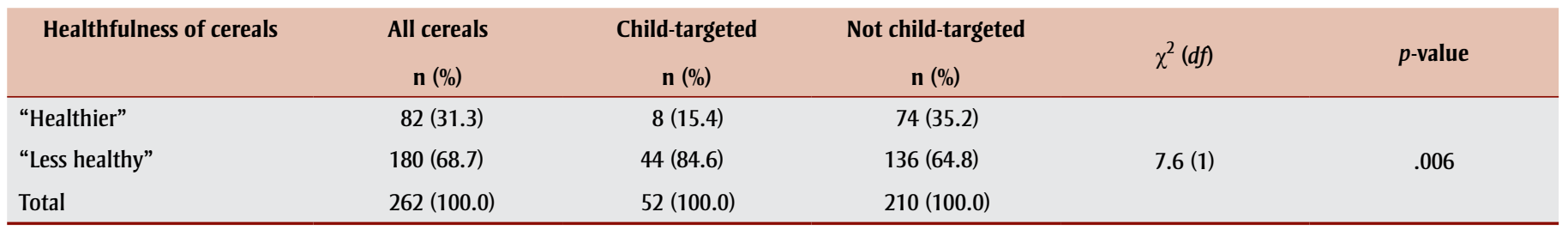

Abbreviation: $d f$, degrees of freedom.

times more likely to be classified as "less healthy" compared to not child-targeted cereals. General Mills had the most childtargeted cereals in our sample $(\mathrm{n}=14$ ) and $100 \%$ of their cereals were classified as "less healthy." Kellogg's was the company responsible for the second-highest number of child-targeted cereals $(n=16)$ and $63 \%$ of their child-targeted cereals were classified as "less healthy." For companies such as Metro ( $\mathrm{n}=6)$, Nature's Path Foods $(\mathrm{n}=5)$, Post $(\mathrm{n}=3)$ and Sally's ( $\mathrm{n}=3$ ), all of their child-targeted cereals were classified as "less healthy." Despite having 10 child-targeted cereals that were classified as "less healthy," Kellogg's distinguished itself by being the company that offered the greatest number of "healthier" child-targeted cereals $(n=6)$. The range of "healthier" cereals by breakfast cereal companies clearly needs to be extended, particularly given the fact that breakfast cereals are heavily promoted to children in other media. ${ }^{16,30}$

Another important finding was that childtargeted cereals were, on average, significantly higher in sugar and sodium, and lower in fibre and protein compared to not child-targeted cereals. The high sugar levels in children's breakfast cereals-30 g per $100 \mathrm{~g}$ of cereal on average (or $31 \%$ of energy) -is worrisome given that research has shown that sugar consumption, especially added sugars, is directly related to obesity. ${ }^{21}$ Our research also showed that no child-targeted cereals were sugar-free, compared to $9 \%$ of not child-targeted cereals. The majority (60\%) of child-targeted cereals had two to three types of added sugar, $23 \%$ of these cereals had four or more types of added sugar, and in $75 \%$ of child-targeted cereals sugar was the second ingredient. Other recent Canadian research has shown that free sugars (i.e. added and naturally occurring sugars in fruit juice) are present in $64 \%$ of all packaged products in Canada. ${ }^{31}$ The World Health Organization recommends reducing individual intake of free sugars to $10 \%$ or less of total energy. ${ }^{32}$ If an average 8-yearold sedentary child, whose caloric intake should be 1500 calories, ${ }^{33}$ consumed $50 \mathrm{~g}$ of a child-targeted cereal, their sugar intake, based on our results, would on average be approximately $15 \mathrm{~g}$ of sugar (or $60 \mathrm{kcal}$ ), which is $40 \%$ of their total free sugars for the day. Given that breakfast cereals are only one source of added sugar in children's diets and that, in the United States, breakfast cereals are ranked as the sixth largest source of sugar for children aged 2 to 18 years after sugar-sweetened beverages, desserts (grain-based), fruit drinks, desserts (dairy-based) and candy, ${ }^{34}$ this child would likely consume far more than

TABLE 3

Number of sugars present in child-targeted and not child-targeted breakfast cereals sold in Ottawa and Gatineau, Canada

\begin{tabular}{lccc} 
Number of sugars & Total cereals & Child-targeted & Not child-targeted \\
\hline 0 & $\mathbf{n}(\%)$ & $\mathbf{n}(\%)$ & $\mathbf{n}(\%)$ \\
1 & $19(7.3)$ & $0(0.0)$ & $19(9.0)$ \\
$2-3$ & $47(17.9)$ & $9(17.3)$ & $38(18.1)$ \\
$4-6$ & $127(48.5)$ & $31(59.6)$ & $96(45.7)$ \\
$7-11$ & $56(21.4)$ & $11(21.2)$ & $45(21.4)$ \\
Total & $13(5.0)$ & $1(1.9)$ & $12(5.7)$ \\
\hline
\end{tabular}

the $10 \%$ sugar limit recommended by WHO. The sugar content of child-targeted cereals needs to be decreased. This could be initially accomplished by federal-level targets for processed foods. Regulations could then be developed, should industry compliance be evaluated as weak. This approach is currently being taken in the United Kingdom, where Public Health England has challenged industry to reduce sugar levels in products frequently consumed by children by at least $20 \%$ by 2020 . If targets are not met, formal regulations will be considered by the government. ${ }^{35}$ Reducing sugar in adult-targeted cereals is also recommended, as even though these cereals had a significantly lower average amount of sugar per $100 \mathrm{~g}$ compared to the child-targeted cereals, a large number (46\%) of not child-targeted cereals in our sample contained two to three different added sugars per cereal, and $27 \%$ had four or more types of added sugar.

In 2015, when the data were collected, labelling policy with regard to sugar permitted food manufacturers to list multiple types of sugar on labels, by weight, in descending order. This policy meant that manufacturers could avoid listing sugar as the first ingredient in a food product by adding many different types of sugar and listing them separately. Health Canada has recently updated the Food and Drug Regulations on food labelling, and sugars must now be grouped in the ingredients list to allow consumers to more easily identify sources of sugar in food products. ${ }^{22}$ Manufacturers have until December 2021 to group sugars together as one ingredient, for example "Ingredients: Sugars (sugar, corn syrup, fructose).” Such a policy may push cereal manufacturers to reduce the amount of sugars in their cereal, as they will likely want to avoid listing sugar as the first ingredient in their products.

Child-targeted cereals were also found to be significantly higher in sodium; on 
TABLE 4

Most frequently occurring top three ingredients for child-targeted and not child-targeted breakfast cereals sold in Ottawa and Gatineau, Canada

\begin{tabular}{|c|c|c|c|c|c|c|c|c|c|}
\hline \multirow[b]{2}{*}{ Ingredient } & \multicolumn{3}{|c|}{$\begin{array}{c}\text { Total } \\
(n=262)\end{array}$} & \multicolumn{3}{|c|}{$\begin{array}{l}\text { Child-targeted } \\
\qquad(n=52)\end{array}$} & \multicolumn{3}{|c|}{$\begin{array}{l}\text { Not child-targeted } \\
\qquad(n=210)\end{array}$} \\
\hline & $\begin{array}{c}1^{\text {st }} \\
\text { n (\%) }\end{array}$ & $\begin{array}{c}2^{\text {nd }} \\
\text { n (\%) }\end{array}$ & $\begin{array}{c}3^{\text {rd }} \\
n(\%)\end{array}$ & $\begin{array}{c}1^{\text {st }} \\
\text { n (\%) }\end{array}$ & $\begin{array}{c}2^{\text {nd }} \\
\text { n (\%) }\end{array}$ & $\begin{array}{c}3^{\text {rd }} \\
\text { n (\%) }\end{array}$ & $\begin{array}{c}1^{\text {st }} \\
\text { n (\%) }\end{array}$ & $\begin{array}{c}2^{\text {nd }} \\
\text { n (\%) }\end{array}$ & $\begin{array}{c}3^{\text {rd }} \\
\text { n (\%) }\end{array}$ \\
\hline Sugar & $8(3.1)$ & $116(44.3)$ & 93 (35.5) & 2 (3.8) & $39(75.0)$ & $17(32.7)$ & $6(2.9)$ & 77 (36.7) & $76(36.2)$ \\
\hline Wheat & $16(6.1)$ & $21(8.0)$ & $17(6.5)$ & 1 (1.9) & $0(0.0)$ & $2(3.8)$ & $15(7.1)$ & $21(10.0)$ & $15(7.1)$ \\
\hline Whole wheat & 49 (18.7) & $27(10.3)$ & $3(1.1)$ & 14 (26.9) & 1 (1.9) & $0(0.0)$ & 35 (16.7) & $26(12.4)$ & $3(1.4)$ \\
\hline Corn & 30 (11.5) & $24(9.2)$ & $17(6.5)$ & $16(30.8)$ & 8 (15.4) & $10(19.2)$ & $14(6.7)$ & $16(7.6)$ & $7(3.3)$ \\
\hline Oat & 102 (38.9) & $16(6.1)$ & $18(6.9)$ & 10 (19.2) & 1 (1.9) & $6(11.5)$ & 92 (43.8) & $15(7.1)$ & $12(5.7)$ \\
\hline Salt & $0(0.0)$ & $0(0.0)$ & $15(5.7)$ & $0(0.0)$ & $0(0.0)$ & $6(11.5)$ & $0(0.0)$ & $0(0.0)$ & $9(4.3)$ \\
\hline Dried fruit & $2(0.8)$ & $6(2.3)$ & $24(9.2)$ & $0(0.0)$ & $0(0.0)$ & $0(0.0)$ & $2(1.0)$ & $6(2.9)$ & 24 (11.4) \\
\hline Oil & $0(0.0)$ & $2(0.8)$ & $19(7.3)$ & $0(0.0)$ & 1 (1.9) & $0(0.0)$ & $0(0.0)$ & $1(0.5)$ & $19(9.0)$ \\
\hline Rice & 31 (11.8) & $9(3.4)$ & $9(3.4)$ & $6(11.5)$ & $0(0.0)$ & $3(5.8)$ & 25 (11.9) & $9(4.3)$ & $6(2.9)$ \\
\hline Nuts & $0(0.0)$ & $0(0.0)$ & $6(2.3)$ & $0(0.0)$ & $0(0.0)$ & $2(3.8)$ & $0(0.0)$ & $0(0.0)$ & 4 (1.9) \\
\hline
\end{tabular}

average they had $440 \mathrm{mg}$ of sodium per $100 \mathrm{~g}$, compared to $226 \mathrm{mg}$ for not childtargeted cereals. Research has shown that as children and adolescents' sodium intake increases, so does their systolic blood pressure and risk for high blood pressure. ${ }^{36,37}$ WHO recommends reducing individual intake of sodium to $2 \mathrm{~g}$ per day for adults, and even less for children, depending on their energy requirements. ${ }^{38}$

Children's breakfast cereals were also significantly lower in fibre. On average, they contained $5 \mathrm{~g}$ of fibre per $100 \mathrm{~g}$ compared to $9 \mathrm{~g}$ per $100 \mathrm{~g}$ in not child-targeted cereals. That means if a child consumed a $50 \mathrm{~g}$ serving of a child-targeted cereal, they would consume only $2.6 \mathrm{~g}$ of fibre on averageonly approximately $10 \%$ of their recommended Adequate Intake of total fibre, which ranges from 25 to $31 \mathrm{~g}$ per day depending on age and sex for children aged 4 to 13 years. ${ }^{39}$ While there have been conflicting results pertaining to the specific relationship between an increased intake of dietary fibre in children and their risk of overweight or obesity, ${ }^{40}$ some research has suggested that an increased amount of dietary fibre in children's diets is an effective means to prevent childhood obesity, ${ }^{41}$ and children whose diets are composed of greater quantities of dietary fibre generally consume less energy from total fat, saturated fat and sucrose. ${ }^{42}$

As with added sugar, sodium content could be decreased, and fibre content could be increased, in breakfast cereals and in other processed foods, through federal-level targets followed by regulations that mandate change if manufacturer's compliance is poor. It is important to keep in mind, however, that food reformulation can be challenging, particularly since nutrients such as sodium, fat and sugar often play a technical role in products. ${ }^{43}$ Salt, for instance, is a preservative that prevents spoilage, while sugar is used for texture or mouthfeel, for preservation and as a bulking agent.

Despite such challenges, the Canadian food and beverage industry has been able to positively reformulate products in the past. A recent evaluation in British Columbia has shown that trans fat use in restaurant foods has declined significantly since an initiative was launched in 2009. ${ }^{44}$ Evidence also shows that breakfast cereal levels of sodium and sugar vary between countries, which indicates that reformulation is possible. Kellogg's Fruit Loops, for instance, has $25 \mathrm{~g}$ of sugar per $100 \mathrm{~g}$ in Kuwait, while in Mexico and Brazil this same product contains $40 \mathrm{~g}$ of sugar. ${ }^{45}$

In addition to reformulating breakfast cereals, it also recommended that regulations be developed that restrict food and beverage marketing to children on product packaging. Research conducted in Canada has shown that self-regulation of marketing through the Children's Food and Beverage Advertising Initiative (CAI) has been ineffective in television and digital advertising; children continue to view high levels of unhealthy food marketing in these media. ${ }^{15-17}$ The failure of self-regulation has also been seen in other countries such as the United States and Australia. ${ }^{46,47}$ Given that the CAI fails to include packaging, children are bombarded with marketing features on breakfast cereal boxes that appeal to children. The Stop Marketing to Kids Coalition, a group of over 25 large nongovernmental health- and child-related organizations under the direction of the Heart and Stroke Foundation and Childhood Obesity Foundation is advocating for the regulation of food and beverage marketing to children and youth in Canada. In its recently developed Ottawa Principles, a recommendation for policy development, the Coalition recommends restricting all food and beverage marketing to children 16 years of age and under. $^{48}$ This recommendation includes defining marketing broadly and including product packaging among other forms of marketing targeted at children. This issue was recently included in the Prime Minister's mandate letter to the Minister of Health. ${ }^{49}$ Health Canada is also currently examining this issue, and government regulations are expected to be proposed in the fall of $2018 .{ }^{50}$ In the fall of 2016, Bill S-228 on marketing to children was also introduced by Senator Greene Raine in the Senate. ${ }^{51}$ This bill calls for an amendment of the Food and Drugs Act that would ban all unhealthy food and beverage marketing to children under the age of 17 years in all forms of media and includes product packaging. Regulation of food marketing to children would level the playing field for 
TABLE 5

Number and percentage of child-targeted and not child-targeted breakfast cereals that are "healthier" and "less healthy," per company, in Ottawa and Gatineau, Canada

\begin{tabular}{|c|c|c|c|}
\hline Company name & $\begin{array}{l}\text { Total } \\
\text { n (\%) }\end{array}$ & $\begin{array}{c}\text { "Healthier" } \\
\text { n (\%) }\end{array}$ & $\begin{array}{c}\text { "Less healthy" } \\
\text { n (\%) }\end{array}$ \\
\hline General Mills & $35(100.0)$ & $4(11.4)$ & 31 (88.6) \\
\hline Child-targeted & $14(100.0)$ & - & $14(100.0)$ \\
\hline Not child-targeted & $21(100.0)$ & $4(19.0)$ & $17(81.0)$ \\
\hline Jordan's (Grain Product Limited) & $10(100.0)$ & - & $10(100.0)$ \\
\hline Child-targeted & - & - & - \\
\hline Not Child-targeted & $10(100.0)$ & - & $10(100.0)$ \\
\hline Kellogg's & $48(100.0)$ & $17(35.4)$ & $31(64.6)$ \\
\hline Child-targeted & $16(100.0)$ & $6(37.5)$ & $10(62.5)$ \\
\hline Not child-targeted & $32(100.0)$ & $11(34.4)$ & $21(65.6)$ \\
\hline Love Grown Foods & $9(100.0)$ & $2(22.2)$ & $7(77.8)$ \\
\hline Child-targeted & - & - & - \\
\hline Not child-targeted & $9(100.0)$ & $2(22.2)$ & $7(77.8)$ \\
\hline Metro & $14(100.0)$ & $6(42.9)$ & $8(57.1)$ \\
\hline Child-targeted & $6(100.0)$ & - & $6(100.0)$ \\
\hline Not child-targeted & $8(100.0)$ & $6(75.0)$ & $2(25.0)$ \\
\hline Nature's Path Foods & $45(100.0)$ & $16(35.6)$ & $29(64.5)$ \\
\hline Child-targeted & $5(100.0)$ & - & $5(100.0)$ \\
\hline Not child-targeted & $40(100.0)$ & $16(40.0)$ & $24(60.0)$ \\
\hline Post & $14(100.0)$ & $5(35.7)$ & $9(64.3)$ \\
\hline Child-targeted & $3(100.0)$ & - & $3(100.0)$ \\
\hline Not child-targeted & $11(100.0)$ & $5(45.5)$ & $6(54.5)$ \\
\hline President's Choice & $32(100.0)$ & $13(40.6)$ & 19 (59.4) \\
\hline Child-targeted & - & - & - \\
\hline Not child-targeted & $32(100.0)$ & $13(40.6)$ & 19 (59.4) \\
\hline Quaker (Pepsi) & $10(100.0)$ & $2(20.0)$ & $8(80.0)$ \\
\hline Child-targeted & $1(100.0)$ & - & $1(100.0)$ \\
\hline Not child-targeted & $9(100.0)$ & $2(22.2)$ & $7(77.8)$ \\
\hline Sally’s (MOM Brands Company) & $9(100.0)$ & $1(11.1)$ & $8(88.9)$ \\
\hline Child-targeted & $3(100.0)$ & - & $3(100.0)$ \\
\hline Not child-targeted & $6(100.0)$ & $1(16.7)$ & $5(83.3)$ \\
\hline Weetabix & $7(100.0)$ & $6(85.7)$ & $1(14.3)$ \\
\hline Child-targeted & $2(100.0)$ & $1(50.0)$ & $1(50.0)$ \\
\hline Not child-targeted & $5(100.0)$ & $5(100.0)$ & - \\
\hline Other Companies & $29(100.0)$ & $10(34.5)$ & $19(65.5)$ \\
\hline Child-targeted & $2(100.0)$ & $1(50.0)$ & $1(50.0)$ \\
\hline Not child-targeted & $27(100.0)$ & $9(33.3)$ & $18(66.7)$ \\
\hline Total (\%) & $262(100.0)$ & 82 (31.3) & $180(68.7)$ \\
\hline
\end{tabular}

breakfast food manufacturers and restrict them from marketing to children on their packaging. Such a step would positively contribute to childhood obesity prevention efforts.

\section{Strengths and limitations}

This study was the first to examine a large sample of Canadian breakfast cereals and systematically categorize them based on their nutritional content and whether they were marketed to children on their product packaging. It is also the first to examine the healthfulness of breakfast cereal companies' product range. Another strength was the use of a validated nutrient profiling system, the UK Nutrient Profile Model, to classify cereals as "healthier" or "less healthy."

Weaknesses include that the cereals examined were those found in a convenience sample of the five largest grocery store chains in Canada, though efforts were made to select stores in different areas of both Ottawa and Gatineau in order to sample the full range of cereals available. Given that cereals were collected in Ottawa (Ontario) and Gatineau (Quebec), the results cannot be generalized to cereals sold in other regions of Canada; however, product lines for major cereal manufacturers are fairly consistent across the country. Future research should examine other foods targeted at children that may have poor nutritional value such as fast food, candy and snacks.

\section{Conclusion}

Given Canada's elevated rates of childhood obesity, evidence highlighting the role and impact of food marketing, and the current evidence showing that breakfast cereals targeting children are not healthy selections, the results of this study point to the importance of including product packaging in restrictions on food and beverage marketing to children. In addition, it is essential for food companies to reformulate their child-targeted breakfast cereals. Such a step could be accomplished through targets set by the federal government. By decreasing the quantity of added sugars and sodium in breakfast cereals, and increasing fibre content, Canadian breakfast cereal companies could positively influence the health of Canadian children.

\section{Acknowledgements}

Thanks to Sony Subedi for her help with the data collection, to Arianne Kent for her translation and editing help and to Elise Pauzé for her help with referencing.

\section{References}

1. Ogden CL, Carroll MD, Kit BK, Flegal KM. Prevalence of childhood and adult obesity in the United States, 2011-2012. JAMA. 2014;311(8):806-14. 
2. World Health Organization. Obesity: situation and trends [Internet]. Geneva (CH): WHO [date unknown; cited 2016 Dec 6]. Available from: http://www .who.int/gho/ncd/risk_factors/obesity _text/en/

3. Robert KC, Shields M, de Groh M, Aziz A, Gilbert JA. Overweight and obesity in children and adolescents: results from the 2009 to 2011 Canadian Health Measures Survey. Health Rep. 2012; 23(3):37-41.

4. Janssen, I. The public health burden of obesity in Canada. Can J Diabetes. 2013;37(2):90-6.

5. McGinnis JM, Gootman JA, Kraak VI, editors. Food marketing to children and youth: threat or opportunity? Washington DC: The National Academies Press; 2006. 516 p.

6. Sadeghirad B, Duhaney T, Motaghipisheh S, Campbell NR, Johnston BC. Influence of unhealthy food and beverage marketing on children's dietary intake and preference: a systematic review and meta-analysis of randomized trials. Obes Rev. 2016;17(10):945-59.

7. Potvin Kent MP, Dubois L, Wanless A. A nutritional comparison of foods and beverages marketed to children in two advertising policy environments. Obesity (Silver Spring). 2012;20(9): 1829-37.

8. Batada A, Seitz MD, Wootan MG, Story M. Nine out of 10 food advertisements shown during Saturday morning children's television programming are for foods high in fat, sodium, or added sugars, or low in nutrients. J Am Diet Assoc. 2008;108(4):673-8.

9. Zuppa JA, Morton H, Mehta KP. Television food advertising: counterproductive to children's health? A content analysis using the Australian Guide to Healthy Eating. Nutr Diet. 2003;60(2):78-85.

10. World Health Organization (WHO). A framework for implementing the set of recommendations on the marketing of foods and non-alcoholic beverages to children. [Internet]. Geneva $(\mathrm{CH})$ : WHO; 2012 [cited 2016 Dec 6]. Available from: http://www.who.int / d i e t p h y s i c a la c t i vi t y /MarketingFramework2012.pdf
11. Advertising Standards Canada. Canadian children's food and beverage advertising initiative [Internet]. Toronto $(\mathrm{ON})$ : Advertising Standards Canada; 2016 [updated 2016 Jan; cited 2016 Dec] Available from: http://www.adstandards .com/en/childrensinitiative/CCFBAI _EN.pdf.

12. Office de la protection du consommateur. Loi sur la protection du consommateur [Internet]. Québec (QC): Office de la protection du consommateur; 2016 [updated 2017 Apr; cited 2016 Dec]. Available from: http://legisquebec .gouv.qc.ca/fr/pdf/cs/P-40.1.pdf

13. Frazier III WC, Harris JL. Trends in television food advertising to young people: 2015 update [Internet]. Hartford (CT): UConn Rudd Center for Food Policy and Obesity; 2016 Jul [cited 2016 Dec] Available from: http:// u c onnrudd center.org / files /TVAdTrends2016.pdf

14. Federal Trade Commission. A review of food marketing to children and adolescents: follow-up report [Internet]. Washington (DC): Federal State Commission; 2012 [cited 2016 July]. Available from: https://www.ftc.gov /sites/default/files/documents/reports /review-food-marketing-children - and-adolescents-follow-report /121221foodmarketingreport.pdf

15. Potvin Kent M, Wanless A. The influence of the Children's Food and Beverage Advertising Initiative: change in children's exposure to food advertising on television in Canada between 2006-2009. Int J Obes (Lond). 2014; 38(4):558-62.

16. Potvin Kent M, Dubois L, Wanless A. Food marketing on children's television in two different policy environments. Int J Pediatr Obes. 2011;6(Suppl 3): e433-e441.

17. Heart and Stroke Foundation. The kids are not alright. How the food and beverage industry is marketing children and youth to death. 2017 report on the health of Canadians [Internet]. Heart and Stroke Foundation; 2017 [cited 2017 April]. Available from: https:// www.heartandstroke.ca/-/media/pdf -files/canada/2017-heart-month /heartandstroke-reportonhealth2017. ashx
18. Harris JL, Schwartz MB, Brownell KD, et al. Cereal FACTS: Limited progress in the nutrition quality and marketing of children's cereals [Internet]. New Haven (CT): Rudd Center for Policy \& Obesity; 2012 [cited 2016 June]. Available from: http://www.cerealfacts .org/media/Cereal_FACTS_Report _2012_7.12.pdf

19. Schwartz MB, Vartanian LR, Wharton $\mathrm{CM}$, Brownell KD. Examining the nutritional quality of breakfast cereals marketed to children. J Am Diet Assoc. 2008;108(4):702-5.

20. Elliott C. Assessing 'fun foods': nutritional content and analysis of supermarket foods targeted at children. Obes Rev. 2008;9(4):368-77.

21. Te Morenga L, Mallard S, Mann J. Dietary sugars and body weight: systematic review and meta-analyses of randomised controlled trials and cohort studies. BMJ [Internet]. 2013 [cited 2016 Jun 21];346:e7492. Available from: http://dx.doi.org/10.1136/bmj.e7492

22. Health Canada. Regulations amending the Food and Drug Regulations (nutrition labelling, other labelling provisions and food colours) [Internet]. Ottawa (ON): Health Canada; 2016 [cited 2017 April]. Available from: http://www .gazette.gc.ca/rp-pr/p2/2016/2016-12 -14/html/sor-dors305-eng.php

23. Sturgeon J. Here's who's really winning Canada's grocery wars [Internet]. Global News, 2014 [updated 2014 Nov 19; cited 2016 Jun]. Available from: http://globalnews.ca/news/1678970 /heres-whos-really-winning-canadas -grocery-wars/

24. Mensink RP, Katan MB. Effect of dietary trans fatty acids on high-density and low-density lipoprotein cholesterol levels in healthy subjects. $\mathrm{N}$ Engl J Med. 1990;323(7):439-45.

25. Canadian Food Inspection Agency (CFIA). List of ingredients and allergens: manner of declaring [Internet]. Ottawa (ON): CFIA; [updated 2016 July, cited 2016 Dec]. Available from http://www .inspection.gc.ca/food/labelling /food-labelling-for-industry/list-of -ingredients-and-allergens/eng/138361 $2857522 / 1383612932341$ ? chap $=2$ 
26. UK Department of Health. Nutrient Profiling Technical Guidance January 2011 [Internet]. London (UK): Department of Health; 2011 [cited 2016 Dec]. Available from: https://www.gov.uk /government/uploads/system/uploads /attachment_data/file/216094/dh _123492.pdf

27. Arambepola C, Scarborough P, Rayner M. Validating a nutrient profile model. Public Health Nutr. 2008;11(4):371-8.

28. Scarborough $\mathrm{P}$, Boxer A, Rayner $\mathrm{M}$, Stockley L. Testing nutrient profile models using data from a survey of nutrition professionals. Public Health Nutr. 2007;10(4):337-45.

29. Romero-Fernández MM, RoyoBordonada MA, Rodríguez-Artalejo F. Evaluation of food and beverage television advertising during children's viewing time in Spain using the UK nutrient profile model. Public Health Nutr. 2013;16(7):1314-20.

30. Potvin Kent M, Martin CL, Kent EA. Changes in the volume, power and nutritional quality of foods marketed to children on television in Canada. Obesity (Silver Spring). 2014;22(9): 2053-60.

31. Bernstein JT, Schermel A, Mills CM, L'Abbé MR. Total and free sugar content of Canadian prepackaged foods and beverages. Nutrients. 2016;8(9):582-604.

32. World Health Organization (WHO). Guideline: sugars intake for adults and children [Internet]. Geneva (CH): WHO; 2015 [cited 2016 Jun]. Available from: http://apps.who.int/iris/bitstream /10665/149782/http://apps.who.int// iris / bitstream/10665/149782/1 /9789241549028_eng.pdf?ua = 1

33. Health Canada. Estimated energy requirements [Internet]. Ottawa (ON): Health Canada [updated 2014 March; cited 2016 Dec]. Available from: http://www .hc-sc.gc.ca/fn-an/food-guide-aliment /basics-base/1_1_1-eng.php

34. Hu FB. Resolved: there is sufficient scientific evidence that decreasing sugar-sweetened beverage consumption will reduce the prevalence of obesity and obesity-related diseases. Obes Rev. 2013;14(8):606-19.
35. HM Government (UK). Childhood obesity: a plan for action [Internet]. London (UK): HM Government [updated 2017 January, cited 2017 April]. Available from: https://www.gov.uk/government / publications/childhood-obesity-a-plan -for-action/childhood-obesity-a-plan -for-action

36. Yang Q, Zhang Z, Kuklina EV, et al. Sodium intake and blood pressure among US children and adolescents. Pediatrics. 2012;130(4):611-9.

37. He FJ, MacGregor GA. Importance of salt in determining blood pressure in children: meta-analysis of controlled trials. Hypertension. 2006;48(5):861-9.

38. World Health Organization (WHO). Guideline: sodium intake for adults and children [Internet]. Geneva $(\mathrm{CH})$ : WHO; 2012 [cited 2016 Jun]. Available from: http://apps.who.int/iris/bitstram /10665/77985/1/9789241504836_eng . pdf?ua $=1 \& u a=1$

39. Institute of Medicine. Chapter 7: Dietary, functional and total fibre. In: Dietary reference intakes for energy, carbohydrate, fiber, fat, fatty acids, cholesterol, protein, and amino acids. Washington (DC): The National Academies Press; 2005. p. 339-422.

40. Kranz S, Brauchla M, Slavin JL, Miller KB. What do we know about dietary fiber intake in children and health? The effects of fiber intake on constipation, obesity, and diabetes in children. Adv Nutr. 2012;3(1):47-53.

41. Kimm SY. The role of dietary fiber in the development and treatment of childhood obesity. Pediatrics. 1995;96(5): 1010-4.

42. Nicklas TA, Farris RP, Myers L, Berenson GS. Dietary fiber intake of children and young adults: the Bogalusa Heart Study. J Am Diet Assoc. 1995;95(2):209-14.

43. Buttriss JL. Food reformulation: the challenges to the food industry. Proc Nutr Soc. 2013;72:61-69.

44. Heart and Stroke Foundation and Government of British Columbia. BC trans fat initiative score card: update April 2014 [Internet]. Victoria (BC): HSF and Government of British Columbia; 2014 [cited 2016 Dec]. Available from: http://www.restricttransfat.ca/media /upload/file/trans-fat-initiative-score -card-april-2014.pdf
45. World Action on Salt and Health (WASH). Global breakfast cereals survey 2016 - full data [Internet]. WASH; 2016 [cited 2017 Apr 12]. Available from http://www.worldactiononsalt .com/less/surveys/2016/190144.pdf

46. Harris J, Schwartz MB, Shehan C, Hyary M, Appel J, Haraghey et al. Snack FACTS 2015: evaluating snack food nutrition and marketing to youth [Internet]. Hartford (CT): Rudd Center for Food Policy \& Obesity; 2015 [cited 2017 Apr]. Available from: http://www.uconnruddcenter.org /files/Pdfs/SnackFACTS_2015 _Fulldraft03.pdf

47. Smithers LG, Lynch J W, Merlin T, Industry self-regulation and $\mathrm{TV}$ advertising of foods to Australian children. J Paediatr Child Health. 2014;50(5):386-92.

48. Stop Marketing to Kids Coalition. The Ottawa Principles [Internet]. Heart and Stroke Foundation; 2016 [cited 2016 Dec]. Available from: http:// stopmarketingtokids.ca/the-ottawa -principles-2/

49. Trudeau J. Minister of Health Mandate Letter [Internet]. Ottawa (ON): Office of the Prime Minster; 2015 [cited 2016 Dec]. Available from: http://pm.gc .ca/eng/minister-health-mandate -letter

50. Health Canada. Toward restricting unhealthy food and beverage marketing to children: discussion paper for public consultation [Internet]. Health Canada; 2017. Available from: https:// s3.ca-central-1.amazonaws.com/ ehq-production-canada/documents /attachments/9bced5c3821050c7084 07be04b299ac6ad286e47/000/006 /633/original/Restricting_Marketing _to_Children.pdf

51. Senate of Canada. Bill S-228: An Act to amend the Food and Drugs Act (prohibiting food and beverage marketing directed at children) [Internet]. Ottawa (ON): Senate of Canada (First Session, Forty-second Parliament); 2016 [cited 2016 Dec]. Available from: http://www.parl.gc.ca/HousePublications /Publication.aspx?Mode $=1 \&$ DocId $=8439399 \&$ Language $=\mathrm{E}$ 